Bond University

Research Repository

\title{
Nonpharmacologic Therapies in Patients With Exacerbation of Chronic Obstructive Pulmonary Disease: A Systematic Review With Meta-Analysis
}

Dobler, Claudia C.; Morrow, Allison S.; Farah, Magdoleen H.; Beuschel, Bradley; Majzoub, Abdul M.; Wilson, Michael E.; Hasan, Bashar; Seisa, Mohamed O.; Daraz, Lubna; Prokop, Larry J.; Murad, M. Hassan; Wang, Zhen

Published in:

Mayo Clinic Proceedings

DOI:

10.1016/j.mayocp.2020.01.018

Licence:

CC BY-NC-ND

Link to output in Bond University research repository.

Recommended citation(APA):

Dobler, C. C., Morrow, A. S., Farah, M. H., Beuschel, B., Majzoub, A. M., Wilson, M. E., Hasan, B., Seisa, M. O., Daraz, L., Prokop, L. J., Murad, M. H., \& Wang, Z. (2020). Nonpharmacologic Therapies in Patients With Exacerbation of Chronic Obstructive Pulmonary Disease: A Systematic Review With Meta-Analysis. Mayo Clinic Proceedings, 95(6), 1169-1183. https://doi.org/10.1016/j.mayocp.2020.01.018

\section{General rights}

Copyright and moral rights for the publications made accessible in the public portal are retained by the authors and/or other copyright owners and it is a condition of accessing publications that users recognise and abide by the legal requirements associated with these rights.

For more information, or if you believe that this document breaches copyright, please contact the Bond University research repository coordinator. 


\section{Non-Pharmacological Therapies in Patients with Exacerbation of COPD: A Systematic Review with Meta-Analysis}

Authors: Claudia C. Dobler, MD, PhD; ${ }^{1,2}$ Allison S. Morrow; BA, ${ }^{1}$ Magdoleen H. Farah, M.B.B.S.; ${ }^{1}$ Bradley Beuschel, BSPH; ${ }^{1}$ Abdul M. Majzoub, M.D., ${ }^{1,3}$ Michael E. Wilson, MD $;{ }^{1,4}$ Bashar Hasan, M.D. $;^{1}$ Mohamed O. Seisa, MD $;{ }^{1}$ Lubna Daraz, Ph.D; ${ }^{1}$ Larry J. Prokop, M.L.S. ${ }^{5}$ M. Hassan Murad, MD, MPH; ${ }^{1}$ Zhen Wang, Ph.D ${ }^{1,6}$

\section{Author affiliations:}

1) Evidence-Based Practice Center, Robert D. and Patricia E. Kern Center for the Science of Health Care Delivery, Mayo Clinic, Rochester, Minnesota

2) Institute for Evidence-Based Healthcare, Bond University and Gold Coast University Hospital, Gold Coast, Queensland, Australia

3) Conemaugh Memorial Medical Center, Johnstown, Pennsylvania

4) Division of Pulmonary and Critical Care Medicine, Rochester, Minnesota

5) Library Public Services, Mayo Clinic, Rochester, Minnesota

6) Division of Health Care Policy and Research, Department of Health Sciences Research, Mayo Clinic, Rochester, Minnesota

This review was primarily performed at Mayo Clinic, Rochester Minnesota.

The authors have not disclosed any potential conflicts of interest.

Word count for abstract: 249

Word count for text: 3,000

Funding/Support: This work was funded by the Agency for Healthcare Research and Quality under a contract (Contract Number: HHSA 290-2015-000131, (PRISM Order Number: HHSA29032005T) to support evidence synthesis as part of the Evidence-based Practice Center Program.

Correspondence to: Claudia C. Dobler, MD, PhD, Evidence-Based Practice Center, Mayo Clinic, 200 First Street SW, Rochester, MN 55905; email: dobler.claudia@mayo.edu; telephone number: 507-284-2511; fax number: 507-266-4372

\section{Email addresses of all authors:}

dobler.claudia@mayo.edu

Morrow.Allison@mayo.edu

beusch.bh@gmail.com

Farah.MagdoleenHassan@mayo.edu

AMajzoub@conemaugh.org

wilson.michael1@mayo.edu

Hasan.Bashar@mayo.edu

seisa.mohamed@mayo.edu

Daraz.Lubna@mayo.edu

Prokop.Larry@mayo.edu

murad.mohammad@mayo.edu

Wang.Zhen@mayo.edu 


\begin{abstract}
Objective: To evaluate the effectiveness and adverse events of non-pharmacological interventions in patients with exacerbation of COPD.

Patients and Methods: We searched Embase, MEDLINE, Cochrane databases, Scopus and clinicaltrials.gov from database inception to January 2, 2019, for randomized controlled trials (RCTs) that enrolled adults with exacerbation of COPD and evaluated the effect of nonpharmacological interventions on clinical outcomes and/or lung function.
\end{abstract}

Results: We included 30 RCTs with 2,643 participants. Improvement in 6-minute walking distance was associated with resistance training (WMD (weighted mean difference) 74.42; 95\% CI: 46.85 to 101.99 ), pulmonary rehabilitation (WMD 20.02; 95\% CI: 12.06 to 28.67), whole body vibration (WMD 89.42; 95\% CI: 45.18 to 133.66) and transcutaneous electrical nerve stimulation (WMD: 64.54; 95\% CI: 53.76 to 75.32). Improvement of quality of life was associated with resistance training (WMD: $18.7 ; 95 \%$ CI: 5.06 to 32.34), combined breathing technique and range of motion exercises (WMD: 14.89; 95\% CI: 5.30 to 24.50), whole body vibration (WMD: -12.02 ; 95\% CI: -21.41 to -2.63 ) and intramuscular vitamin D (WMD: 4.67; $95 \%$ CI: -6.00 to -3.35 at the longest follow-up). Oxygen titration with a target oxygen saturation range of $88 \%-92 \%$ was associated with reduced mortality compared with high flow oxygen (OR: 0.36 ; $95 \%$ CI: 0.14 to 0.88 ). All findings were based on low strength of evidence.

Conclusion: In patients hospitalized for exacerbation of COPD, exercise interventions and pulmonary rehabilitation programs may ameliorate functional decline. Oxygen should be titrated with a target oxygen saturation of $88-92 \%$ in these patients.

Study Registration: PROSPERO Identifier: CRD42018111609 


\section{Introduction}

Exacerbations of chronic obstructive pulmonary disease (COPD) are the leading cause of increased mortality and morbidity in COPD. ${ }^{1-3}$ Antibiotics, systemic corticosteroids and short-acting bronchodilators are the cornerstones of the management of exacerbations of COPD but non-pharmacological interventions may also play a role. ${ }^{4}$ There is growing awareness that careful oxygen titration in an acute setting with a target oxygen saturation rate (to avoid oversupply of oxygen) may be beneficial not only in COPD patients with known hypercapnic respiratory failure but in COPD patients in general. ${ }^{5}$ Chest physiotherapy is frequently used to clear pulmonary secretions from the lungs, but there is uncertainty about its effectiveness to improve health outcomes. ${ }^{3}$ Pulmonary rehabilitation is an effective intervention to improve health outcomes in patients with stable COPD or patients who have stabilized after an episode of COPD exacerbation. ${ }^{6}$ More recently, pulmonary rehabilitation in patients hospitalized for exacerbation of COPD has become a focus of interest, in particular as a potential tool to ameliorate deconditioning. Malnutrition is relatively common among patients with COPD. ${ }^{7}$ During an exacerbation, factors such as loss of appetite and reduced dietary intake, physical inactivity, inflammation, hypoxaemia and the use of systemic corticosteroids may induce or accelerate weight loss and muscle wasting. Nutritional assessment and therapy during exacerbations of COPD is recommended, ${ }^{9}$ but the impact of nutritional interventions during exacerbations on health outcomes is uncertain. There are other non-pharmacological interventions such as whole body vibration training and transcutaneous electrical nerve stimulation which only relatively recently have been considered for treatment during exacerbations of COPD. The objective of this systematic review was to evaluate the impact of non-pharmacological interventions compared with usual care on health outcomes in individuals experiencing an exacerbation of COPD. 


\section{Methods}

The systematic review was guided by a study protocol (PROSPERO Identifier: CRD42018111609, https://effectivehealthcare.ahrq.gov/products/copd/protocol), which we developed with input from clinical and methodological experts and professional organizations, and was generated from an AHRQ report (https://effectivehealthcare.ahrq.gov/products/copd/research).

\section{Date sources and searches}

We searched Embase, Epub Ahead of Print, In-Process \& Other Non-Indexed Citations, MEDLINE Daily, MEDLINE, Cochrane Central Registrar of Controlled Trials, Ovid Cochrane Database of Systematic Reviews, and Scopus) and clinicaltrials.gov from database inception to January 2, 2019. We also searched grey literature and conducted reference mining. The databases, grey literature, and detailed search strategy are listed in eTable 1 in the Supplement.

\section{Study selection}

We included randomized controlled trials (RCTs) published in English that enrolled patients 18 years and older with exacerbation of COPD. Studies had to compare a nonpharmacological intervention with placebo, a sham procedure, or management without intervention in outpatients, hospitalized patients or patients attending an emergency department. We excluded studies conducted in the intensive care unit (ICU), chronic ventilator unit, or respiratory care unit and studies that assessed invasive and non-invasive 
mechanical ventilation in any study setting. Studies had to assess at least one of the following outcomes: repeat exacerbations; dyspnea; mortality; quality of life; hospital readmission; ICU admission; functional capacity (timed walking tests, endurance tests); need for intubation; symptoms; lung function; adverse event (AE).

Independent reviewers, working in pairs, screened the titles and abstracts of all citations and the full text of studies included by either reviewer. Disagreements were resolved through consensus in consultation with a third reviewer.

\section{Data extraction and risk of bias assessment}

We developed a standardized data extraction form to extract study characteristics. Reviewers worked independently to extract study details. Data extraction and risk of bias assessment were completed by pairs of independent reviewers. We used the Cochrane Collaboration's Risk of Bias tool to assess risk of bias at a study and outcome level. ${ }^{10}$

\section{Data Synthesis and Analysis}

We summarized RCTs by type of intervention, comparator, and outcomes. Statistical analyses were based on the intention-to-treat principle. We extracted or calculated the odds ratio (OR) and corresponding 95-percent confidence intervals for binary outcomes. For continuous outcomes, we calculated the standardized mean difference (SMD) when different measures for the same outcome were reported (e.g. different quality of life measurement tools). We also standardized the direction of the measures with higher scores representing better outcomes when different measurement tools were used. We calculated weighted mean difference (WMD) when the included studies used the same outcome measure. Hospital readmissions and repeat exacerbations were based on number of persons with at least one 
event (binary outcome) as well as the number of events, for which the rate ratio was calculated by dividing the incidence rate of events in the intervention group by the incidence in the control group. For AEs, we also calculated the rate ratio. We used the definition of serious AEs listed by the original studies. Mortality and repeat exacerbation were reported as effectiveness outcomes and not reported as serious AEs in this review. AEs were categorized (eTable 2 in the Supplement).

Interventions labelled as pulmonary rehabilitation in original studies were classified as aerobic and/or resistance exercise interventions if they only contained an exercise component and were not multi-faceted interventions.

We narratively synthesized crossover RCTs as they had significant reporting and methodological weaknesses, such as missing data and failure to control within-individual difference.

We used the DerSimonian and Laird (D-L) random effect method to combine direct comparisons between treatments if the number of studies included in the analysis was larger than $3{ }^{6,11}$ We used the fixed effect method based on the Mantel and Haenszel method due to instability of between-study variance, when the number of studies in a meta-analysis was 3 or less. ${ }^{12}$ We were unable to statistically evaluate publication bias due to the small number of studies included in each meta-analysis. ${ }^{13}$ All statistical analyses were conducted using Stata/SE version 15.1 (StataCorp LLC, College Station, TX).

\section{Grading the Strength of Evidence}


The strength of evidence (SOE) for each outcome was designated as high, moderate, low, or 'insufficient evidence to estimate an effect' (definitions appear in eTable 3 in the Supplement). ${ }^{14}$

\section{Results}

Thirty citations that represented 30 unique $\mathrm{RCTs}^{15-44}$ and 2,643 participants were included in the analysis (eFigure 1 in the Supplement) All trials were conducted in patients with moderate or severe exacerbation of COPD. 28 studies $^{16-18,20-44}$ were conducted in hospitalized patients, one ${ }^{19}$ in both outpatients and hospital settings, and one in an ambulance. ${ }^{15}$ Studies were conducted in the Canada (3), Europe (13), Asia (9), Australia (4), Africa (8), and South America (1). One study was a crossover $\mathrm{RCT}^{28}$ Average length of the intervention was 11.33 days, and the mean reported follow-up time was 4.46 months. Details of the interventions used in each study can be found in eTable 4 in the Supplement.

The overall risk of bias in the included studies was intermediate to high due to unclear sequence generation (36.67\%), unclear allocation concealment $(60.00 \%)$, and high risk or unclear risk of incomplete outcome data $(60.00 \%)$ (eTable 5 in the Supplement). Results for primary and secondary effectiveness outcomes can be found in Table 1 and eTable 6 in the Supplement respectively. AEs and withdrawals are listed in eTable 7 in the Supplement.

\section{Airway clearance techniques}

We identified seven RCTs ${ }^{16,19,21,23,28,29,34}$ with airway clearance technique interventions using either breathing technique, ${ }^{16,21,28}$ vibration or percussion, ${ }^{19,23,29}$ or positive expiratory pressure ${ }^{43}$ compared with management without these interventions. Breathing technique was 
associated with reduced hospital readmissions at the longest follow-up ( $\mathrm{N}=2$; Rate Ratio: 0.91 ; $95 \%$ CI: 0.83 to $0.99, \mathrm{I}^{2}=79.5 \%$, Low SOE $)^{21,28}$ but not with any other outcomes. No association of vibration/percussions ${ }^{19,23,29}$ or positive expiratory pressure ${ }^{34}$ with any effectiveness outcomes was observed. Serious AEs reported in the positive expiratory pressure group included 9 cases of serious clinical deterioration (all-causes) and 3 cases of acute sputum retention. ${ }^{34}$

\section{Exercise}

Eight RCTs evaluated exercise interventions including resistance training (of which two used upper and lower limb resistance training ${ }^{18,39}$ and one used lower limb resistance training only $^{41}$ ), aerobic exercise $\mathrm{e}^{17,20,27,40}$ and a combination of resistance training and aerobic exercise $^{38}$ compared with management without these interventions. The SOE for all outcomes was low.

Resistance training was associated with better quality of life (WMD: 18.70; 95\% CI: 5.06 to $32.34),{ }^{39}$ reduced dyspnea (N=1; WMD: $-2.11 ; 95 \% \mathrm{CI}:-3.50$ to -0.72$),{ }^{39}$ and longer $6-$ minute walking distance (N=2; WMD: 74.42 ; $95 \%$ CI: 46.85 to $\left.101.99 ; \mathrm{I}^{2}=95.42 \%\right),{ }^{18,41}$ but not with other outcomes or number of withdrawals. Aerobic exercise was associated with improved dyspnea (N=1; WMD: 7.20; 95\% CI: 4.53 to 9.87) and quality of life (WMD: 38.00; 95\% CI: 24.51 to 51.49$),{ }^{17}$ number of steps walked per day $(\mathrm{N}=1$; WMD: $663.03 ; 95 \%$ CI: 496.34 to 829.72$)^{40}$ and endurance based on a 30 -second sit-to-stand test $(\mathrm{N}=1$; WMD: $4.63 ; 95 \%$ CI: 2.54 to 6.72$)^{40}$ at the end of intervention but worse dyspnea $(\mathrm{N}=1$; WMD: 1.20; 95\% CI: 0.33 to 2.07$).{ }^{20}$ One $\mathrm{RCT}^{38}$ compared combined aerobic and resistance training, using a low intensity and a moderate to high-intensity exercise group, vs management without aerobic and resistance training. Independent of intensity, combined 
aerobic and resistance training was not significantly associated with 3-minute walking distance, upper limb muscle strength, forced expiratory volume in 1 second (FEV1) \% predicted and number total of AEs. ${ }^{38}$

\section{Breathing technique and range of motion exercises combined}

A combination of breathing technique and range of motion exercises was associated with improvement in quality of life (N=1; WMD: 14.89 ; $95 \%$ CI: 5.30 to 24.50 , Low SOE) ${ }^{39}$ but not dyspnea or FEV1 \% predicted, compared with management without breathing technique and range of motion exercises in one RCT. ${ }^{39}$

\section{Multi-faceted pulmonary rehabilitation program}

Four RCTs ${ }^{20,22,24,26,31}$ compared pulmonary rehabilitation vs management without pulmonary rehabilitation. The SOE for all outcomes was low. Pulmonary rehabilitation was associated with a longer 6-minute walking distance (N=3; WMD: 20.02; 95\% CI: 12.06 to 28.67;

$\left.\mathrm{I}^{2}=79.08 \%\right),{ }^{22,26,31}$ decreased dyspnea (based on a numeric scale) at the end of the intervention ( $\mathrm{N}=2$; SMD: 0.66 ; $95 \%$ CI: 0.31 to 1.00 ; $\left.\mathrm{I}^{2}=89.21 \%\right)^{26,31}$ but not at the longest follow-up, and decreased cough (N=1; WMD: -2.00 ; $95 \%$ CI: -2.98 to -1.02$).{ }^{31}$ Risk of readmission was similar in both groups $(\mathrm{N}=1$; HR: $1.19,95 \% \mathrm{CI}: 0.90$ to 1.60$) .{ }^{24}$ There was no significant difference between the intervention and control group in serious AEs, total number of AEs, withdrawals, and withdrawals due to AEs.

\section{Whole body vibration}

Whole body vibration training was compared with management without whole body vibration training in one $\mathrm{RCT},{ }^{25}$ which found that the intervention was associated with higher 
quality of life (WMD: $-12.02 ; 95 \%$ CI: -21.41 to -2.63 ; $\mathrm{I}^{2}=\mathrm{N} / \mathrm{A}$, Low SOE) and a longer 6minute walking distance (WMD: 89.42; 95\% CI: 45.18 to 133.66, Low SOE).

\section{Transcutaneous Electrical Nerve Stimulation}

One $\mathrm{RCT}^{33}$ evaluated Transcutaneous Electrical Nerve Stimulation (TENS) vs management without TENS. TENS was associated with longer 6-minute walking distance (WMD: 64.54; 95\% CI: 53.76 to 75.32 , Low SOE) but not with dyspnea, FEV1 and number of withdrawals.

\section{Oxygen}

We identified 3 RCTs with an oxygen intervention; one trial assessed supplemental oxygen vs supplemental air during mobilization with a walking aid, ${ }^{44}$ one RCT evaluated titrated vs high flow oxygen; ${ }^{15}$ and one RCT compared vs manual oxygen titration. ${ }^{30}$ Supplemental oxygen during mobilization with a walking aid (gutter frame or rollator) was not significantly associated with mortality, 30-day hospital readmissions, dyspnea, number of withdrawals, and total number of AEs, compared with supplemental air. Hypoxemia at rest was not a requirement for inclusion in this study ( $\mathrm{paCO} 2$ ranged from $72-80 \mathrm{mmHg}$ at baseline), and oxygen levels were not measured during mobilization. One RCT compared titrated oxygen (with a target oxygen saturation between $88 \%$ and $92 \%$ delivered by nasal prongs) vs high flow oxygen (8-10 liters/min, administered by a non-rebreather face mask $)^{15}$ in patients transported to hospital via ambulance. Titrated oxygen was associated with reduced mortality (OR: 0.36 ; $95 \%$ CI: 0.14 to 0.88 , Low SOE). Approximately $70 \%$ of deaths occurred within the first five days of admission for both treatment arms. Automated oxygen saturation 
titration compared with manual titration was not significantly associated with mortality and other effective outcomes in another RCT. ${ }^{30}$

\section{Dietary interventions}

Each of the following interventions was assessed by one RCT: caloric supplement vs usual diet; ${ }^{37}$ caloric and a protein supplement vs placebo (non-caloric fluid, vanilla flavored water) ${ }^{43}$ and high fat low carbohydrate diet vs usual diet ${ }^{42}$; and omega-3 fatty acid enriched diet vs usual diet. ${ }^{32}$ There were no significant associations between any of the interventions and effectiveness outcomes and AEs.

Two studies ${ }^{35,36}$ evaluated the effectiveness of vitamin D (taken orally or given as an intramuscular injection) compared with placebo. Vitamin D was associated with better quality of life based on the St George's Respiratory Questionnaire at the end of the intervention ( $\mathrm{N}=1$; WMD: -1.96 ; $95 \% \mathrm{CI}$ : -2.89 to -1.03 , Low SOE), ${ }^{35}$ and at the longest follow-up (N=1; WMD: -4.67 ; 95\% CI: -6.00 to -3.35 , Low SOE).$^{35}$ No statistical difference was found in the number of withdrawals due to AEs.

\section{Discussion}

In this systematic review with meta-analyses, exercise, multi-faceted pulmonary rehabilitation programs, whole body vibration and transcutaneous electrical nerve stimulation (TENS) were associated with improved functional outcomes (primarily based on the 6minute waking distance) in patients hospitalized for moderate or severe exacerbation of COPD. Resistance training, combined breathing technique and range of motion exercises, whole body vibration and intramuscular vitamin $\mathrm{D}$ were associated with better quality of life. Oxygen titration with a target oxygen saturation range of $88 \%-92 \%$ was associated with 
reduced mortality compared with high flow oxygen. Seventeen of the 30 studies (57\%) reported AEs or number of withdrawals. Reported AEs were generally mild. We found no significant differences in AEs and serious AEs between non- pharmacological therapies and control groups. There was a lack of trials that compared pharmacological with nonpharmacological therapies or combinations thereof (other than multi-faceted pulmonary rehabilitation programs).

Breathing technique was the only airway clearance technique associated with an improved clinical outcome (reduced hospital readmissions at the longest follow-up). A previous Cochrane review from 2012 reported a reduction in the need for ventilatory support (invasive or non-invasive), length of time on ventilatory support and length of hospital stay associated with airway clearance teachniques. ${ }^{45}$ This was based on studies conducted in patients requiring non-invasive ventilation, ${ }^{46,47}$ patients treated in the ICU, ${ }^{48}$ and patients treated for exacerbation of chronic bronchitis (rather than COPD), ${ }^{49}$ all of which were excluded in our review. Our review did, however, include five new RCTs not previously included in the Cochrane review. ${ }^{16,34,50-52}$ It is possible that patients with an exacerbation at the most severe end of the spectrum, requiring ventilatory support and/or treatment in the ICU stand to benefit the most from airway clearance techniques.

Our review showed evidence of benefits from exercise during hospitalization for moderate to severe exacerbation of COPD using resistance or aerobic exercise for functional outcomes (primarily 6-minute walking distance). These benefits were visible in exercise only interventions as well as in multifaceted pulmonary rehabilitation programs, which we analyzed separately. The American Thoracic Society/European Respiratory Society guidelines published in 2017 made a conditional recommendation (very low quality of 
evidence) to not initiate pulmonary rehabilitation during hospitalization for exacerbation of COPD. ${ }^{53}$ This was based on a meta-analysis of two RCTs ${ }^{54,55}$ that showed that patients with exacerbation of COPD who started pulmonary rehabilitation in hospital had increased mortality (50 deaths in 210 patients in the intervention group, 32 deaths in 205 patients in the control group; RR 1.54, 95\% CI 1.03 to 2.29 ). The results were driven by a trial of rehabilitation commenced within 48 hours of hospital admission in 389 patients with exacerbations of different chronic respiratory conditions (patients with exacerbation of COPD constituted $82 \%$ of the cohort) that found an increase in mortality in the intervention group at one year (49 deaths in196 patients in the intervention group, 31 deaths in 193 patients in the control group; OR $1.74,95 \%$ CI 1.05 to 2.88$).{ }^{54}$ Given the potential of pulmonary rehabilitation commenced in hospital to ameliorate the functional decline associated with exacerbation of COPD, high quality RCTs with careful safety monitoring of patients to determine its potential benefits and harms are needed to determine the optimal timing of pulmonary rehabilitation.

One trial found reduced mortality with oxygen titration using a target oxygen saturation between $88 \%$ and $92 \%$ compared with high flow oxygen (8-10 liters/min) during ambulance transport to the hospital in cohort in which hypercapnic respiratory failure was highly prevalent. ${ }^{15} \mathrm{~A}$ target oxygen range of $88 \%-92 \%$ is now the accepted standard of practice in patients with exacerbation of COPD in many settings, supported by British guidelines. ${ }^{56}$ It remains unclear whether such a target oxygen range is only beneficial in patients at risk of hypercapnic respiratory failure or whether patients with exacerbation of COPD but absence of hypercapnia stand to benefit as well. 
High-Flow Nasal Cannula is a relatively recently introduced system delivering heated humidified air-oxygen mixture with the ability to deliver a high fraction of inspired oxygen and generate a low level of positive pressure. It is currently unclear whether High-Flow Nasal Cannula is associated with improved clinical outcomes compared with conventional oxygen therapy or non-invasive ventilation in exacerbation of COPD. ${ }^{57,58}$

For most interventions, only one RCT was available per outcome which limits inferences from the quantitative synthesis. Failure to detect statistical significance for most of the outcomes may have resulted from type II error. All studies were conducted in hospitalized patients with moderate to severe exacerbation of COPD, and the results may therefore not be applicable to patients with milder forms of exacerbation of COPD treated in an outpatient setting. As we excluded studies conducted in an intensive care setting and/or in patients requiring ventilator support, some of our findings may not be extrapolated to the most severely sick patients with exacerbation of COPD. The included studies were overall at high risk of bias. The evaluation of AEs was limited as the majority of the included studies (43\%) did not evaluate or report AEs.

The treatment options of whole body vibration, transcutaneous electrical nerve stimulation (TENS) and vitamin D, which showed improved functional outcomes and betters quality of life respectively in our review, need to be assessed in large high quality RCTs to inform recommendations about these treatments. Such literature (e.g., on vitamin D) is notorious for contradictory findings over time. Trials are needed that compare pharmacological with nonpharmacological therapies or combinations thereof. 


\section{Conclusion}

The findings of the systematic review and meta-analyses highlight that some nonpharmacologic interventions hold promise for improving clinically important outcomes in particular they might improve functional capacity and thus mitigate the deconditioning associated with exacerbation of COPD.

\section{Abbreviations}

AE: adverse event

CI: confidence interval

COPD: chronic obstructive pulmonary disease

FEV1: forced expiratory volume in 1 second

ICU: intensive care unit

$\mathrm{N}$ : number

OR: odds ratio

RCT: randomized controlled trial

SOE: strength of evidence

TENS: transcutaneous electrical nerve stimulation

WMD: weighted mean difference

\section{Acknowledgments}


We would like to thank Lionel L. Bañez (AHRQ Project Officer) and John W. Williams (EPC Associate Editor) for their input.

\section{Author Contributions}

Drs. Dobler and Wang had full access to all data in the study and take responsibility for the integrity of the data and the accuracy of the data analysis.

Study concept and design: Dobler, Wang, Murad.

Acquisition, analysis or interpretation of the data: Dobler, Morrow, Beuschel, Farah,

Majzoub, Wilson, Hasan, Seisa, Daraz, Prokop, Wang, Murad.

Drafting of the manuscript: Dobler, Wang, Murad

Critical revision of manuscript for important intellectual content: Dobler, Morrow, Beuschel, Farah, Majzoub, Wilson, Hasan, Seisa, Daraz, Prokop, Wang, Murad.

Statistical analysis: Wang, Murad

Obtaining funding: Wang, Murad.

Administrative, technical, or material support: Morrow.

Study supervision: Wang, Murad.

Conflicts of Interest Disclosures: All authors have completed and submitted the International Committee of Medical Journal Editors Form for Disclosure of Potential Conflicts of Interest. The authors have no conflicts of interests to disclose.

Funding: Funding/Support: This work was funded by the Agency for Healthcare Research and Quality under a contract (Contract Number: HHSA 290-2015-000131, PRISMA Order Number: HHSA29032005T) to support evidence synthesis as part of the Evidence-based Practice Center Program. 
Role of the Funder/Sponsor: The funder had no role in the design and conduct of the study; collection, management, analysis, and interpretation of the data; preparation, review, or approval of the manuscript; and decision to submit the manuscript for publication.

Disclaimer: The findings and conclusions in this article are those of the authors, who are responsible for its contents. The findings and conclusions do not necessarily represent the views of the Agency for Healthcare Research and Quality or the US government. Therefore, no statement in this article should be construed as the official position of the Agency for Healthcare Research and Quality. 
Table 1. Primary Effectiveness Outcomes in Adult Patients with Exacerbation of COPD

\begin{tabular}{|c|c|c|c|c|c|}
\hline Comparison & Outcome & Findings & $\begin{array}{c}\text { Study Design } \\
\text { and Sample } \\
\text { Size }\end{array}$ & $\begin{array}{l}\text { Rationale for } \\
\text { Strength of } \\
\text { Evidence } \\
\text { (SOE) }\end{array}$ & $\begin{array}{c}\text { Overall } \\
\text { Strength of } \\
\text { Evidence }\end{array}$ \\
\hline \multirow{6}{*}{$\begin{array}{l}\text { Airway clearance } \\
\text { techniques using } \\
\text { breathing technique } \\
\text { versus management } \\
\text { without airway clearance } \\
\text { techniques }\end{array}$} & $\begin{array}{l}\text { Mortality } \\
\text { End of intervention }\end{array}$ & $\begin{array}{l}\text { OR: } 0.97 ; \\
95 \% \mathrm{Cl}: 0.06 \\
\text { to } 16.20, \mathrm{I}^{2}= \\
\text { N/A }\end{array}$ & $\begin{array}{l}1 \mathrm{RCT}^{28} \text { with } \\
59 \text { patients }\end{array}$ & $\begin{array}{l}\text { High ROB } \\
\text { and severe } \\
\text { imprecision }\end{array}$ & $\begin{array}{l}\text { Insufficient } \\
\text { evidence }\end{array}$ \\
\hline & $\begin{array}{l}\text { Mortality } \\
\text { Longest Followup }\end{array}$ & $\begin{array}{l}\text { OR: } 0.90 ; \\
95 \% \mathrm{Cl}: 0.54 \\
\text { to } 1.49, \mathrm{I}^{2}= \\
\text { N/A }\end{array}$ & $\begin{array}{l}1 \mathrm{RCT}^{21} \text { with } \\
522 \text { patients }\end{array}$ & $\begin{array}{l}\text { Intermediate } \\
\text { ROB and } \\
\text { imprecision }\end{array}$ & $\begin{array}{l}\text { Low SOE } \\
\text { supporting no } \\
\text { difference }\end{array}$ \\
\hline & $\begin{array}{l}\text { Dyspnea } \\
\text { (Questionnaire: } \\
\text { MRC) } \\
\text { End of Intervention }\end{array}$ & $\begin{array}{l}\text { WMD: } 0.40 ; \\
95 \% \mathrm{Cl}:-0.24 \\
\text { to } 1.04, \mathrm{I}^{2}= \\
\text { N/A }\end{array}$ & $\begin{array}{l}1 \mathrm{RCT}^{28} \text { with } \\
59 \text { patients }\end{array}$ & $\begin{array}{l}\text { High ROB } \\
\text { and severe } \\
\text { imprecision }\end{array}$ & $\begin{array}{l}\text { Insufficient } \\
\text { evidence }\end{array}$ \\
\hline & $\begin{array}{l}\text { Dyspnea } \\
\text { (Numeric Scale: } \\
\text { VAS, Borg) } \\
\text { End of Intervention }\end{array}$ & $\begin{array}{l}\text { SMD: }-0.42 ; \\
95 \% \mathrm{Cl}:-0.89 \\
\text { to } 0.05 \text {, } \\
\left.\right|^{2}=98.92 \%\end{array}$ & $\begin{array}{l}2 \mathrm{RCT}^{16,28} \text { with } \\
119 \text { patients }\end{array}$ & $\begin{array}{l}\text { High ROB, } \\
\text { inconsistency } \\
\text { and severe } \\
\text { imprecision }\end{array}$ & $\begin{array}{l}\text { Insufficient } \\
\text { evidence }\end{array}$ \\
\hline & $\begin{array}{l}\text { QoL(SGRQ) } \\
\text { End of Intervention }\end{array}$ & $\begin{array}{l}\text { SMD: }-0.02 ; \\
95 \% \mathrm{Cl}:-0.18 \\
\text { to } 0.14 \\
\left.\right|^{2}=0.00 \%\end{array}$ & $\begin{array}{l}2 \mathrm{RCTs}^{21,28} \text { with } \\
581 \text { patients }\end{array}$ & $\begin{array}{l}\text { High ROB } \\
\text { and severe } \\
\text { imprecision }\end{array}$ & $\begin{array}{l}\text { Insufficient } \\
\text { evidence }\end{array}$ \\
\hline & $\begin{array}{l}\text { Hospital } \\
\text { Readmission } \\
\text { Longest Followup }\end{array}$ & $\begin{array}{l}\text { Rate Ratio: } \\
0.91 ; 95 \% \mathrm{Cl} \text { : } \\
0.83 \text { to } 0.99 \\
\left.\right|^{2}=79.5 \%\end{array}$ & $\begin{array}{l}2 \mathrm{RCTs}^{21,28} \text { with } \\
581 \text { patients }\end{array}$ & $\begin{array}{l}\text { High ROB, } \\
\text { and } \\
\text { inconsistency }\end{array}$ & $\begin{array}{l}\text { Low SOE } \\
\text { supporting } \\
\text { reduction }\end{array}$ \\
\hline \multirow{3}{*}{$\begin{array}{l}\text { Airway clearance } \\
\text { techniques using } \\
\text { vibration, percussion, or } \\
\text { massage versus } \\
\text { management without } \\
\text { airway clearance } \\
\text { techniques }\end{array}$} & $\begin{array}{l}\text { Dyspnea } \\
\text { (Questionnaire: } \\
\text { MRC; MMRC) } \\
\text { End of Intervention }\end{array}$ & $\begin{array}{l}\text { SMD: } 0.15 ; \\
95 \% \mathrm{Cl}:-0.29 \\
\text { to } 0.60, \mathrm{I}^{2}= \\
0.00 \%\end{array}$ & $\begin{array}{l}2 \mathrm{RCTs}^{23,29} \text { with } \\
80 \text { patients }\end{array}$ & $\begin{array}{l}\text { High ROB } \\
\text { and severe } \\
\text { imprecision }\end{array}$ & $\begin{array}{l}\text { Insufficient } \\
\text { evidence }\end{array}$ \\
\hline & $\begin{array}{l}\text { Dyspnea } \\
\text { (Questionnaire: } \\
\text { MMRC) } \\
\text { Longest Followup }\end{array}$ & $\begin{array}{l}\text { WMD: }-0.24 ; \\
95 \% \mathrm{Cl}:-0.73 \\
\text { to } 0.25, \mathrm{I}^{2}= \\
\text { N/A }\end{array}$ & $\begin{array}{l}1 \mathrm{RCT}^{23} \text { with } 50 \\
\text { patients }\end{array}$ & $\begin{array}{l}\text { High ROB } \\
\text { and severe } \\
\text { imprecision }\end{array}$ & $\begin{array}{l}\text { Insufficient } \\
\text { evidence }\end{array}$ \\
\hline & $\begin{array}{l}\text { 6MWD } \\
\text { End of Intervention }\end{array}$ & $\begin{array}{l}\text { WMD: } 56.20 ; \\
95 \% \mathrm{Cl}:-8.18 \\
\text { to } 120.58, \mathrm{I}^{2}= \\
\text { N/A }\end{array}$ & $\begin{array}{l}1 \mathrm{RCT}^{29} \text { with } 30 \\
\text { patients }\end{array}$ & $\begin{array}{l}\text { High ROB } \\
\text { and severe } \\
\text { imprecision }\end{array}$ & $\begin{array}{l}\text { Insufficient } \\
\text { evidence }\end{array}$ \\
\hline \multirow{7}{*}{$\begin{array}{l}\text { Airway clearance } \\
\text { techniques using positive } \\
\text { expiratory pressure } \\
\text { versus management } \\
\text { without positive airway } \\
\text { clearance techniques }\end{array}$} & $\begin{array}{l}\text { Mortality } \\
\text { End of Intervention }\end{array}$ & $\begin{array}{l}\text { OR: } 1.00 ; \\
95 \% \mathrm{Cl}: 0.06 \\
\text { to } 16.48, \mathrm{I}^{2}= \\
\mathrm{N} / \mathrm{A}\end{array}$ & $\begin{array}{l}1 \mathrm{RCT}^{34} \text { with } 92 \\
\text { patients }\end{array}$ & $\begin{array}{l}\text { Severe } \\
\text { imprecision }\end{array}$ & $\begin{array}{l}\text { Low SOE } \\
\text { supporting no } \\
\text { difference }\end{array}$ \\
\hline & $\begin{array}{l}\text { Mortality } \\
\text { Longest Followup }\end{array}$ & $\begin{array}{l}\text { OR: } 1.58 ; \\
95 \% \mathrm{Cl}: 0.41 \\
\text { to } 6.00, \mathrm{I}^{2}= \\
\text { N/A }\end{array}$ & $\begin{array}{l}1 \mathrm{RCT}^{34} \text { with } 92 \\
\text { patients }\end{array}$ & $\begin{array}{l}\text { Severe } \\
\text { imprecision }\end{array}$ & $\begin{array}{l}\text { Low SOE } \\
\text { supporting no } \\
\text { difference }\end{array}$ \\
\hline & $\begin{array}{l}\text { Dyspnea } \\
\text { (Questionnaire: } \\
\text { MMRC) } \\
\text { End of Intervention }\end{array}$ & $\begin{array}{l}\text { WMD: } 0.40 ; \\
95 \% \mathrm{Cl}:-0.16 \\
\text { to } 0.96, \mathrm{I}^{2}= \\
\text { N/A }\end{array}$ & $\begin{array}{l}1 \mathrm{RCT}^{34} \text { with } 92 \\
\text { patients }\end{array}$ & $\begin{array}{l}\text { Severe } \\
\text { imprecision }\end{array}$ & $\begin{array}{l}\text { Low SOE } \\
\text { supporting no } \\
\text { difference }\end{array}$ \\
\hline & $\begin{array}{l}\text { Dyspnea } \\
\text { (Questionnaire: } \\
\text { MMRC) } \\
\text { Longest Followup }\end{array}$ & $\begin{array}{l}\text { WMD: } 0.50 ; \\
95 \% \mathrm{Cl}:-0.06 \\
\text { to } 1.06, \mathrm{I}^{2}= \\
\text { N/A }\end{array}$ & $\begin{array}{l}1 \mathrm{RCT}^{34} \text { with } 92 \\
\text { patients }\end{array}$ & $\begin{array}{l}\text { Severe } \\
\text { imprecision }\end{array}$ & $\begin{array}{l}\text { Low SOE } \\
\text { supporting no } \\
\text { difference }\end{array}$ \\
\hline & $\begin{array}{l}\text { Repeat } \\
\text { Exacerbation } \\
\text { End of Intervention }\end{array}$ & $\begin{array}{l}\text { OR: } 1.00 ; \\
95 \% \mathrm{Cl}: 0.06 \\
\text { to } 16.48, \mathrm{I}^{2}= \\
\mathrm{N} / \mathrm{A}\end{array}$ & $\begin{array}{l}1 \mathrm{RCT}^{34} \text { with } 92 \\
\text { patients }\end{array}$ & $\begin{array}{l}\text { Severe } \\
\text { imprecision }\end{array}$ & $\begin{array}{l}\text { Low SOE } \\
\text { supporting no } \\
\text { difference }\end{array}$ \\
\hline & $\begin{array}{l}\text { Repeat } \\
\text { Exacerbation } \\
\text { Longest Followup }\end{array}$ & $\begin{array}{l}\text { Rate Ratio: } \\
1.05 ; 95 \% \\
0.69 \text { to } 1.59 \\
\left.\right|^{2}=\text { N/A }\end{array}$ & $\begin{array}{l}1 \mathrm{RCT}^{34} \text { with } 92 \\
\text { patients }\end{array}$ & $\begin{array}{l}\text { Severe } \\
\text { imprecision }\end{array}$ & $\begin{array}{l}\text { Low SOE } \\
\text { supporting no } \\
\text { difference }\end{array}$ \\
\hline & QoL(SGRQ) & WMD: -1.50; & $1 \mathrm{RCT}^{34}$ with 92 & Severe & Low SOE \\
\hline
\end{tabular}




\begin{tabular}{|c|c|c|c|c|c|}
\hline & Longest Followup & $\begin{array}{l}95 \% \mathrm{Cl}:-5.99 \\
\text { to } 8.99, \mathrm{I}^{2}= \\
\text { N/A }\end{array}$ & patients & imprecision & $\begin{array}{l}\text { supporting no } \\
\text { difference }\end{array}$ \\
\hline & $\begin{array}{l}6 \mathrm{MWD} \\
\text { End of Intervention }\end{array}$ & $\begin{array}{l}\text { WMD:-26.00; } \\
95 \% \mathrm{Cl}:- \\
89.61 \text { to } \\
37.62, \mathrm{I}^{2}= \\
\text { N/A }\end{array}$ & $\begin{array}{l}1 \mathrm{RCT}^{34} \text { with } 92 \\
\text { patients }\end{array}$ & $\begin{array}{l}\text { Severe } \\
\text { imprecision }\end{array}$ & $\begin{array}{l}\text { Low SOE } \\
\text { supporting no } \\
\text { difference }\end{array}$ \\
\hline & $\begin{array}{l}\text { 6MWD } \\
\text { Longest Followup }\end{array}$ & $\begin{array}{l}\text { WMD: }-4.00 ; \\
95 \% \mathrm{Cl}:- \\
82.49 \text { to } \\
74.49, \mathrm{I}^{2}= \\
\text { N/A }\end{array}$ & $\begin{array}{l}1 \mathrm{RCT}^{34} \text { with } 92 \\
\text { patients }\end{array}$ & $\begin{array}{l}\text { Severe } \\
\text { imprecision }\end{array}$ & $\begin{array}{l}\text { Low SOE } \\
\text { supporting no } \\
\text { difference }\end{array}$ \\
\hline \multirow[t]{5}{*}{$\begin{array}{l}\text { Exercise using resistance } \\
\text { training versus vs } \\
\text { management without } \\
\text { resistance training }\end{array}$} & $\begin{array}{l}\text { Mortality } \\
\text { Longest Followup }\end{array}$ & $\begin{array}{l}\text { OR: } 0.22 ; \\
95 \% \mathrm{Cl}: 0.01 \\
\text { to } 4.81, \mathrm{I}^{2}= \\
\text { N/A }\end{array}$ & $\begin{array}{l}1 \mathrm{RCT}^{18} \text { with } 46 \\
\text { patients }\end{array}$ & $\begin{array}{l}\text { Intermediate } \\
\text { ROB and } \\
\text { severe } \\
\text { imprecision }\end{array}$ & $\begin{array}{l}\text { Insufficient } \\
\text { evidence }\end{array}$ \\
\hline & $\begin{array}{l}\text { Dyspnea } \\
\text { (Numeric Scale; } \\
\text { Modified Borg) } \\
\text { End of Intervention }\end{array}$ & $\begin{array}{l}\text { WMD: }-2.11 \\
95 \% \text { Cl: }- \\
3.50 \text { to }-0.72 \text {, } \\
\mathrm{I}^{2}=\mathrm{N} / \mathrm{A}\end{array}$ & $\begin{array}{l}1 \mathrm{RCT}^{39} \text { with } 60 \\
\text { patients }\end{array}$ & $\begin{array}{l}\text { Intermediate } \\
\text { ROB and } \\
\text { imprecision }\end{array}$ & $\begin{array}{l}\text { Low SOE } \\
\text { supporting } \\
\text { improvement }\end{array}$ \\
\hline & $\begin{array}{l}\text { QoL(EQ-5D VAS) } \\
\text { End of Intervention }\end{array}$ & $\begin{array}{l}\text { WMD: } 18.70 \\
95 \% \text { Cl: } 5.06 \\
\text { to } 32.34, I^{2}= \\
\text { N/A }\end{array}$ & $\begin{array}{l}1 \mathrm{RCT}^{39} \text { with } 60 \\
\text { patients }\end{array}$ & $\begin{array}{l}\text { Intermediate } \\
\text { ROB and } \\
\text { imprecision }\end{array}$ & $\begin{array}{l}\text { Low SOE } \\
\text { supporting } \\
\text { improvement }\end{array}$ \\
\hline & $\begin{array}{l}\text { Hospital } \\
\text { Readmission } \\
\text { Longest Followup }\end{array}$ & $\begin{array}{l}\text { OR: } 1.23 ; \\
95 \% \mathrm{Cl}: 0.35 \\
\text { to } 4.31, \mathrm{I}^{2}= \\
\text { N/A }\end{array}$ & $\begin{array}{l}1 \mathrm{RCT}^{41} \text { with } 40 \\
\text { patients }\end{array}$ & $\begin{array}{l}\text { High ROB } \\
\text { and severe } \\
\text { imprecision }\end{array}$ & $\begin{array}{l}\text { Insufficient } \\
\text { evidence }\end{array}$ \\
\hline & $\begin{array}{l}6 \mathrm{MWD} \\
\text { End of Intervention }\end{array}$ & $\begin{array}{l}\text { WMD: } 74.42 ; \\
95 \% \mathrm{Cl}: 46.85 \\
\text { to } 101.99, \mathrm{I}^{2}= \\
95.42 \%\end{array}$ & $\begin{array}{l}2 \mathrm{RCTs}^{18,41} \text { with } \\
86 \text { patients }\end{array}$ & $\begin{array}{l}\text { High ROB, } \\
\text { and } \\
\text { imprecision }\end{array}$ & $\begin{array}{l}\text { Low SOE } \\
\text { supporting } \\
\text { improvement }\end{array}$ \\
\hline \multirow[t]{8}{*}{$\begin{array}{l}\text { Exercise using aerobic } \\
\text { training versus vs } \\
\text { management without } \\
\text { aerobic training }\end{array}$} & $\begin{array}{l}\text { Mortality } \\
\text { End of Intervention }\end{array}$ & $\begin{array}{l}\text { OR: } 1.00 ; \\
95 \% \mathrm{Cl}: 0.06 \\
\text { to } 17.02, \mathrm{I}^{2}= \\
\text { N/A }\end{array}$ & $\begin{array}{l}1 \mathrm{RCT}^{17} \text { with } \\
46 \text { patients }\end{array}$ & $\begin{array}{l}\text { High ROB } \\
\text { and severe } \\
\text { imprecision }\end{array}$ & $\begin{array}{l}\text { Insufficient } \\
\text { evidence }\end{array}$ \\
\hline & $\begin{array}{l}\text { Dyspnea } \\
\text { (Questionnaire: } \\
\text { Transitional } \\
\text { Dyspnea Index) } \\
\text { End of Intervention }\end{array}$ & $\begin{array}{l}\text { WMD: } 7.20 \\
95 \% \mathrm{Cl}: 4.53 \\
\text { to } 9.87, \mathrm{I}^{2}= \\
\text { N/A }\end{array}$ & $\begin{array}{l}1 \mathrm{RCT}^{17} \text { with } \\
46 \text { patients }\end{array}$ & $\begin{array}{l}\text { High ROB } \\
\text { and } \\
\text { imprecision }\end{array}$ & $\begin{array}{l}\text { Low SOE } \\
\text { supporting } \\
\text { better } \\
\text { outcome }\end{array}$ \\
\hline & $\begin{array}{l}\text { Dyspnea } \\
\text { (Questionnaire: } \\
\text { MRC) } \\
\text { Longest Followup }\end{array}$ & $\begin{array}{l}\text { WMD: } 1.20 ; \\
95 \% \text { Cl: } 0.33 \\
\text { to } 2.07, I^{2}= \\
\text { N/A }\end{array}$ & $\begin{array}{l}1 \mathrm{RCT}^{20} \text { with } 29 \\
\text { patients }\end{array}$ & $\begin{array}{l}\text { Intermediate } \\
\text { ROB, and } \\
\text { imprecision }\end{array}$ & $\begin{array}{l}\text { Low SOE } \\
\text { supporting } \\
\text { worse } \\
\text { outcome } \\
\end{array}$ \\
\hline & $\begin{array}{l}\text { QoL (CRQ) } \\
\text { End of Intervention }\end{array}$ & $\begin{array}{l}\text { WMD: } 38.00 ; \\
95 \% \text { Cl: } \\
24.51 \text { to } \\
51.49, I^{2}= \\
\text { N/A }\end{array}$ & $\begin{array}{l}1 \mathrm{RCT}^{17} \text { with } \\
46 \text { patients }\end{array}$ & $\begin{array}{l}\text { High ROB } \\
\text { and } \\
\text { imprecision }\end{array}$ & $\begin{array}{l}\text { Low SOE } \\
\text { supporting } \\
\text { better } \\
\text { outcome }\end{array}$ \\
\hline & $\begin{array}{l}\text { QoL(CAT) } \\
\text { Longest Followup }\end{array}$ & $\begin{array}{l}\text { WMD: }-5.20 ; \\
95 \% \mathrm{Cl}:- \\
2.99 \text { to } \\
13.39, \mathrm{I}^{2}= \\
\text { N/A }\end{array}$ & $\begin{array}{l}1 \mathrm{RCT}^{20} \text { with } 29 \\
\text { patients }\end{array}$ & $\begin{array}{l}\text { Intermediate } \\
\text { ROB and } \\
\text { severe } \\
\text { imprecision }\end{array}$ & $\begin{array}{l}\text { Insufficient } \\
\text { evidence }\end{array}$ \\
\hline & \multirow[t]{2}{*}{$\begin{array}{l}\text { Hospital } \\
\text { Readmission } \\
\text { Longest Followup }\end{array}$} & $\begin{array}{l}\text { OR: } 1.50 ; \\
95 \% \mathrm{Cl}: 0.33 \\
\text { to } 6.77, \mathrm{I}^{2}= \\
\mathrm{N} / \mathrm{A}\end{array}$ & $\begin{array}{l}1 \mathrm{RCT}^{20} \text { with } 29 \\
\text { patients }\end{array}$ & $\begin{array}{l}\text { Intermediate } \\
\text { ROB and } \\
\text { severe } \\
\text { imprecision }\end{array}$ & $\begin{array}{l}\text { Insufficient } \\
\text { evidence }\end{array}$ \\
\hline & & $\begin{array}{l}\text { Rate Ratio: } \\
0.96 ; 95 \% \mathrm{Cl} \text { : } \\
0.39 \text { to } 2.37 \\
\mathrm{I}^{2}=\mathrm{N} / \mathrm{A}\end{array}$ & $\begin{array}{l}1 \mathrm{RCT}^{20} \text { with } 29 \\
\text { patients }\end{array}$ & $\begin{array}{l}\text { Intermediate } \\
\text { ROB and } \\
\text { severe } \\
\text { imprecision }\end{array}$ & $\begin{array}{l}\text { Insufficient } \\
\text { evidence }\end{array}$ \\
\hline & $\begin{array}{l}\text { Repeat } \\
\text { Exacerbation }\end{array}$ & $\begin{array}{l}\text { OR: } 0.74 \\
\text { 95\% Cl: } 0.22\end{array}$ & $\begin{array}{l}2 \mathrm{RCTs}^{2017} \text { with } \\
75 \text { patients }\end{array}$ & $\begin{array}{l}\text { High ROB } \\
\text { and severe }\end{array}$ & $\begin{array}{l}\text { Insufficient } \\
\text { evidence }\end{array}$ \\
\hline
\end{tabular}




\begin{tabular}{|c|c|c|c|c|c|}
\hline & End of Intervention & $\begin{array}{l}\text { to } 2.49, I^{2}= \\
0.0 \%\end{array}$ & & imprecision & \\
\hline & $\begin{array}{l}6 \mathrm{MWD} \\
\text { End of Intervention }\end{array}$ & $\begin{array}{l}\text { WMD: } 28.71 ; \\
95 \% \text { Cl: } \\
10.91 \text { to } \\
46.50, \mathrm{I}^{2}= \\
98.4 \%\end{array}$ & $\begin{array}{l}2 \text { RCTs }^{1727} \\
\text { with } 75 \text { patients }\end{array}$ & $\begin{array}{l}\text { High ROB, } \\
\text { and } \\
\text { imprecision }\end{array}$ & $\begin{array}{l}\text { Low SOE } \\
\text { supporting } \\
\text { improvement }\end{array}$ \\
\hline $\begin{array}{l}\text { Exercise using combined } \\
\text { aerobic + resistance } \\
\text { training versus } \\
\text { management without } \\
\text { exercise training } \\
\text { Low Intensity Exercise } \\
\text { Group vs management } \\
\text { without exercise training }\end{array}$ & $\begin{array}{l}\text { 3-minute Walking } \\
\text { Distance Test } \\
\text { End of Intervention }\end{array}$ & $\begin{array}{l}\text { SMD: } 0.40 \\
95 \% \mathrm{Cl}:- \\
0.50 \text { to } 1.30 \\
\mathrm{I}^{2}=\mathrm{N} / \mathrm{A}\end{array}$ & $\begin{array}{l}1 \mathrm{RCT}^{38} \text { with } 22 \\
\text { patients }\end{array}$ & $\begin{array}{l}\text { Severe } \\
\text { imprecision }\end{array}$ & $\begin{array}{l}\text { Low SOE } \\
\text { supporting no } \\
\text { difference }\end{array}$ \\
\hline $\begin{array}{l}\text { Exercise using combined } \\
\text { aerobic + resistance } \\
\text { training versus } \\
\text { management without } \\
\text { exercise training } \\
\text { Moderate-to-High } \\
\text { Intensity Exercise Group } \\
\text { vs management without } \\
\text { exercise training }\end{array}$ & $\begin{array}{l}\text { 3-minute Walking } \\
\text { Distance Test }\end{array}$ & $\begin{array}{l}\text { No statistical } \\
\text { difference } \\
\text { between the } \\
\text { intervention } \\
\text { and the } \\
\text { control }\end{array}$ & $\begin{array}{l}1 \mathrm{RCT}^{38} \text { with } 22 \\
\text { patients }\end{array}$ & $\begin{array}{l}\text { Severe } \\
\text { imprecision }\end{array}$ & $\begin{array}{l}\text { Low SOE } \\
\text { supporting no } \\
\text { difference }\end{array}$ \\
\hline \multirow{2}{*}{$\begin{array}{l}\text { Breathing technique and } \\
\text { range of motion } \\
\text { exercises combined } \\
\text { (breathing } \\
\text { technique+range of } \\
\text { motion exercises) } \\
\text { combined versus } \\
\text { management without } \\
\text { exercise training }\end{array}$} & $\begin{array}{l}\text { Dyspnea } \\
\text { (Numeric Scale: } \\
\text { Modified Borg } \\
\text { Scale) } \\
\text { End of Intervention }\end{array}$ & $\begin{array}{l}\text { WMD: } 1.15 \\
95 \% \text { Cl: }- \\
0.61 \text { to } 2.91 \\
\mathrm{I}^{2}=\mathrm{N} / \mathrm{A}\end{array}$ & $\begin{array}{l}1 \mathrm{RCT}^{39} \text { with } 60 \\
\text { patients }\end{array}$ & $\begin{array}{l}\text { Intermediate } \\
\text { ROB and } \\
\text { severe } \\
\text { imprecision }\end{array}$ & $\begin{array}{l}\text { Insufficient } \\
\text { evidence }\end{array}$ \\
\hline & $\begin{array}{l}\text { QoL } \\
\text { (EQ-5D) } \\
\text { End of Intervention }\end{array}$ & $\begin{array}{l}\text { WMD: } 14.89 ; \\
95 \% \text { Cl: } 5.30 \\
\text { to } 24.50, I^{2}= \\
\text { N/A }\end{array}$ & $\begin{array}{l}1 \mathrm{RCT}^{39} \text { with } 60 \\
\text { patients }\end{array}$ & $\begin{array}{l}\text { Intermediate } \\
\text { ROB } \\
\text { imprecision }\end{array}$ & $\begin{array}{l}\text { Low SOE } \\
\text { supporting } \\
\text { improvement }\end{array}$ \\
\hline \multirow{8}{*}{$\begin{array}{l}\text { Multi-faceted pulmonary } \\
\text { rehabilitation program } \\
\text { (breathing } \\
\text { technique+range of } \\
\text { motion exercises) } \\
\text { combined versus } \\
\text { management without } \\
\text { multi-faceted pulmonary } \\
\text { rehabilitation program }\end{array}$} & $\begin{array}{l}\text { Mortality } \\
\text { End of Intervention }\end{array}$ & $\begin{array}{l}\text { OR: } 3.26 ; \\
95 \% \mathrm{Cl}: 0.13 \\
\text { to } 81.98 \\
\mathrm{I}^{2}=\mathrm{N} / \mathrm{A}\end{array}$ & $\begin{array}{l}1 \mathrm{RCT}^{22} \text { with } 97 \\
\text { patients }\end{array}$ & $\begin{array}{l}\text { High ROB } \\
\text { and severe } \\
\text { imprecision }\end{array}$ & $\begin{array}{l}\text { Insufficient } \\
\text { evidence }\end{array}$ \\
\hline & $\begin{array}{l}\text { Dyspnea } \\
\text { (Questionnaire: } \\
\text { MMRC) } \\
\text { End of Intervention }\end{array}$ & $\begin{array}{l}\text { WMD: }-0.50 ; \\
95 \% \mathrm{Cl}:- \\
3.01 \text { to } 2.06 \text {, } \\
\mathrm{I}^{2}=\mathrm{N} / \mathrm{A}\end{array}$ & $\begin{array}{l}1 \mathrm{RCT}^{26} \text { with } 94 \\
\text { patients }\end{array}$ & $\begin{array}{l}\text { High ROB } \\
\text { and severe } \\
\text { imprecision }\end{array}$ & $\begin{array}{l}\text { Insufficient } \\
\text { evidence }\end{array}$ \\
\hline & $\begin{array}{l}\text { Dyspnea } \\
\text { (Questionnaire: } \\
\text { MMRC) } \\
\text { Longest Followup } \\
\end{array}$ & $\begin{array}{l}\text { WMD: } 0.04 ; \\
95 \% \mathrm{Cl}:- \\
0.48 \text { to } 0.56 \text {, } \\
\mathrm{I}^{2}=\mathrm{N} / \mathrm{A}\end{array}$ & $\begin{array}{l}1 \mathrm{RCT}^{26} \text { with } 94 \\
\text { patients }\end{array}$ & $\begin{array}{l}\text { High ROB } \\
\text { and severe } \\
\text { imprecision }\end{array}$ & $\begin{array}{l}\text { Insufficient } \\
\text { evidence }\end{array}$ \\
\hline & $\begin{array}{l}\text { Dyspnea } \\
\text { (Numeric Scale: } \\
\text { Modified Borg; } \\
\text { Borg) } \\
\text { End of Intervention }\end{array}$ & $\begin{array}{l}\text { SMD: } 0.66 ; \\
95 \% \text { Cl: } 0.31 \\
\text { to } 1.00 \\
I^{2}=89.21 \%\end{array}$ & $\begin{array}{l}2 \mathrm{RCT}^{26,31} \text { with } \\
156 \text { patients }\end{array}$ & $\begin{array}{l}\text { High ROB } \\
\text { and } \\
\text { inconsistency }\end{array}$ & $\begin{array}{l}\text { Low SOE } \\
\text { supporting } \\
\text { improvement }\end{array}$ \\
\hline & $\begin{array}{l}\text { Dyspnea } \\
\text { (Numeric Scale: } \\
\text { Borg) } \\
\text { Longest Followup }\end{array}$ & $\begin{array}{l}\text { WMD: } 0.20 \\
95 \% \mathrm{Cl}:- \\
0.69 \text { to } 0.29 \\
\mathrm{I}^{2}=\mathrm{N} / \mathrm{A}\end{array}$ & $\begin{array}{l}1 \mathrm{RCT}^{22} \text { with } 97 \\
\text { patients }\end{array}$ & $\begin{array}{l}\text { High ROB } \\
\text { and severe } \\
\text { imprecision }\end{array}$ & $\begin{array}{l}\text { Insufficient } \\
\text { evidence }\end{array}$ \\
\hline & \multirow[t]{3}{*}{$\begin{array}{l}\text { Hospital } \\
\text { Readmission } \\
\text { at } 30 \text { days }\end{array}$} & $\begin{array}{l}\text { OR: } 0.65 ; \\
95 \% \mathrm{Cl}: 0.26 \\
\text { to } 1.60, \mathrm{I}^{2}= \\
\mathrm{N} / \mathrm{A}\end{array}$ & $\begin{array}{l}1 \mathrm{RCT}^{22} \text { with } \\
97 \text { patients }\end{array}$ & $\begin{array}{l}\text { High ROB } \\
\text { and severe } \\
\text { imprecision }\end{array}$ & $\begin{array}{l}\text { Insufficient } \\
\text { evidence }\end{array}$ \\
\hline & & $\begin{array}{l}\text { Rate Ratio: } \\
0.60 ; 95 \% \mathrm{Cl}: \\
0.31 \text { to } 1.15 \\
\mathrm{I}^{2}=\mathrm{N} / \mathrm{A}\end{array}$ & $\begin{array}{l}1 \mathrm{RCT}^{22} \text { with } \\
97 \text { patients }\end{array}$ & $\begin{array}{l}\text { High ROB } \\
\text { and severe } \\
\text { imprecision }\end{array}$ & $\begin{array}{l}\text { Insufficient } \\
\text { evidence }\end{array}$ \\
\hline & & $\begin{array}{l}\text { Hazard } \\
\text { Ratio: } 1.19 ; \\
95 \% \mathrm{Cl}: 0.90 \\
\text { to } 1.60, \mathrm{I}^{2}=\end{array}$ & $\begin{array}{l}1 \mathrm{RCT}^{24} \text { with } \\
320 \text { patients }\end{array}$ & $\begin{array}{l}\text { High ROB } \\
\text { and severe } \\
\text { imprecision }\end{array}$ & $\begin{array}{l}\text { Insufficient } \\
\text { evidence }\end{array}$ \\
\hline
\end{tabular}




\begin{tabular}{|c|c|c|c|c|c|}
\hline & & $\mathrm{N} / \mathrm{A}$ & & & \\
\hline & $\begin{array}{l}6 \mathrm{MWD} \\
\text { End of Intervention }\end{array}$ & $\begin{array}{l}\text { WMD: } 20.02 \\
95 \% \mathrm{Cl}: 12.06 \\
\text { to } 28.67 \\
\mathrm{I}^{2}=79.08 \%\end{array}$ & $\begin{array}{l}3 \mathrm{RCTs}^{22,26,31} \\
\text { with } 253 \\
\text { patients }\end{array}$ & $\begin{array}{l}\text { High ROB, } \\
\text { and } \\
\text { imprecision }\end{array}$ & $\begin{array}{l}\text { Low SOE } \\
\text { supporting } \\
\text { improvement }\end{array}$ \\
\hline \multirow[t]{2}{*}{$\begin{array}{l}\text { Whole body vibration } \\
\text { training during AECOPD } \\
\text { versus management } \\
\text { without whole body }\end{array}$} & $\begin{array}{l}\text { QoL(SGRQ) } \\
\text { End of Intervention }\end{array}$ & $\begin{array}{l}\text { WMD: }- \\
12.02 ; 95 \% \\
\mathrm{Cl}:-21.41 \text { to } \\
-2.63, \mathrm{I}^{2}=\mathrm{N} / \mathrm{A}\end{array}$ & $\begin{array}{l}1 \mathrm{RCT}^{25} \text { with } \\
49 \text { patients }\end{array}$ & $\begin{array}{l}\text { Intermediate } \\
\text { ROB and } \\
\text { imprecision }\end{array}$ & $\begin{array}{l}\text { Low SOE } \\
\text { supporting } \\
\text { improvement }\end{array}$ \\
\hline & $\begin{array}{l}6 \mathrm{MWD} \\
\text { End of Intervention }\end{array}$ & $\begin{array}{l}\text { WMD: } 89.42 ; \\
95 \% \text { Cl: } \\
45.18 \\
\text { to133.66, I²= } \\
\text { N/A }\end{array}$ & $\begin{array}{l}1 \mathrm{RCT}^{25} \text { with } 49 \\
\text { patients }\end{array}$ & $\begin{array}{l}\text { Intermediate } \\
\text { ROB and } \\
\text { imprecision }\end{array}$ & $\begin{array}{l}\text { Low SOE } \\
\text { supporting } \\
\text { improvement }\end{array}$ \\
\hline \multirow{2}{*}{$\begin{array}{l}\text { Transcutaneous electrical } \\
\text { nerve stimulation (TENS) } \\
\text { during AECOPD versus } \\
\text { Management without } \\
\text { Transcutaneous } \\
\text { Electrical Nerve } \\
\text { Stimulation }\end{array}$} & $\begin{array}{l}\text { Dyspnea } \\
\text { (Questionnaire: } \\
\text { MRC) } \\
\text { End of Intervention }\end{array}$ & $\begin{array}{l}\text { WMD: }-0.23 \\
95 \% \mathrm{Cl}:- \\
0.57 \text { to } 0.11 \\
\mathrm{I}^{2}=\mathrm{N} / \mathrm{A}\end{array}$ & $\begin{array}{l}1 \mathrm{RCT}^{33} \text { with } 82 \\
\text { patients }\end{array}$ & $\begin{array}{l}\text { High ROB } \\
\text { and severe } \\
\text { imprecision }\end{array}$ & $\begin{array}{l}\text { Insufficient } \\
\text { evidence }\end{array}$ \\
\hline & $\begin{array}{l}\text { 6MWD } \\
\text { End of Intervention }\end{array}$ & $\begin{array}{l}\text { WMD: } 64.54 ; \\
95 \% \mathrm{Cl}: 53.76 \\
\text { to } 75.32, \mathrm{I}^{2}= \\
\text { N/A }\end{array}$ & $\begin{array}{l}1 \mathrm{RCT}^{33} \text { with } \\
82 \text { patients }\end{array}$ & $\begin{array}{l}\text { High ROB } \\
\text { and } \\
\text { imprecision }\end{array}$ & $\begin{array}{l}\text { Low SOE } \\
\text { supporting } \\
\text { improvement }\end{array}$ \\
\hline \multirow[t]{3}{*}{$\begin{array}{l}\text { Gutter Frame with } \\
\text { Supplemental Oxygen vs. } \\
\text { Gutter Frame with } \\
\text { Supplemental Air }\end{array}$} & $\begin{array}{l}\text { Dyspnea } \\
\text { (Numeric: Borg } \\
\text { Dyspnea Scale) } \\
\text { End of intervention }\end{array}$ & $\begin{array}{l}\text { WMD: } 0.80 \\
95 \% \mathrm{Cl}:- \\
0.90 \text { to } 2.50 \\
\mathrm{I}^{2}=\mathrm{N} / \mathrm{A}\end{array}$ & $\begin{array}{l}1 \mathrm{RCT}^{44} \text { with } 60 \\
\text { patients }\end{array}$ & $\begin{array}{l}\text { High ROB } \\
\text { and severe } \\
\text { imprecision }\end{array}$ & $\begin{array}{l}\text { Insufficient } \\
\text { evidence }\end{array}$ \\
\hline & $\begin{array}{l}\text { Mortality } \\
\text { Longest Followup }\end{array}$ & $\begin{array}{l}\text { OR:1.00; } \\
95 \% \mathrm{Cl}: 0.06 \\
\text { to } 16.76 \\
\mathrm{I}^{2}=\mathrm{N} / \mathrm{A}\end{array}$ & $\begin{array}{l}1 \mathrm{RCT}^{44} \text { with } 60 \\
\text { patients }\end{array}$ & $\begin{array}{l}\text { High ROB } \\
\text { and severe } \\
\text { imprecision }\end{array}$ & $\begin{array}{l}\text { Insufficient } \\
\text { evidence }\end{array}$ \\
\hline & $\begin{array}{l}\text { Hospital } \\
\text { Readmission } \\
30 \text { days }\end{array}$ & $\begin{array}{l}\text { OR: } 1.63 ; \\
95 \% \mathrm{Cl}: 0.41 \\
\text { to } 6.47 \\
\mathrm{I}^{2}=\mathrm{N} / \mathrm{A}\end{array}$ & $\begin{array}{l}1 \mathrm{RCT}^{44} \text { with } 60 \\
\text { patients }\end{array}$ & $\begin{array}{l}\text { High ROB } \\
\text { and severe } \\
\text { imprecision }\end{array}$ & $\begin{array}{l}\text { Insufficient } \\
\text { evidence }\end{array}$ \\
\hline \multirow[t]{3}{*}{$\begin{array}{l}\text { Rollator with } \\
\text { Supplemental Oxygen, } \\
\text { vs. Rollator with } \\
\text { Supplemental Air }\end{array}$} & $\begin{array}{l}\text { Dyspnea } \\
\text { (Numeric: Borg } \\
\text { Dyspnea Scale) } \\
\text { End of Intervention }\end{array}$ & $\begin{array}{l}\text { WMD: }-0.90 \\
95 \% \mathrm{Cl}:- \\
2.35 \text { to } 0.58 \\
\mathrm{I}^{2}=\mathrm{N} / \mathrm{A}\end{array}$ & $\begin{array}{l}1 \mathrm{RCT}^{44} \text { with } 60 \\
\text { patients }\end{array}$ & $\begin{array}{l}\text { High ROB } \\
\text { and severe } \\
\text { imprecision }\end{array}$ & $\begin{array}{l}\text { Insufficient } \\
\text { evidence }\end{array}$ \\
\hline & $\begin{array}{l}\text { Mortality } \\
\text { Longest Followup }\end{array}$ & $\begin{array}{l}0 \text { cases in } \\
\text { both groups }\end{array}$ & $\begin{array}{l}1 \mathrm{RCT}^{44} \text { with } 60 \\
\text { patients }\end{array}$ & $\begin{array}{l}\text { High ROB } \\
\text { and severe } \\
\text { imprecision }\end{array}$ & $\begin{array}{l}\text { Insufficient } \\
\text { evidence }\end{array}$ \\
\hline & $\begin{array}{l}\text { Hospital } \\
\text { Readmission } \\
30 \text { days }\end{array}$ & $\begin{array}{l}\text { OR: } 1.63 \\
95 \% \text { Cl: } 0.41 \\
\text { to } 6.47 \\
I^{2}=\mathrm{N} / \mathrm{A}\end{array}$ & $\begin{array}{l}1 \mathrm{RCT}^{44} \text { with } 60 \\
\text { patients }\end{array}$ & $\begin{array}{l}\text { High ROB } \\
\text { and severe } \\
\text { imprecision }\end{array}$ & $\begin{array}{l}\text { Insufficient } \\
\text { evidence }\end{array}$ \\
\hline \multirow[t]{2}{*}{$\begin{array}{l}\text { Titrated oxygen vs high } \\
\text { flow oxygen }\end{array}$} & $\begin{array}{l}\text { Mortality } \\
\text { Longest Followup }\end{array}$ & $\begin{array}{l}\text { OR: } 0.36 ; \\
95 \% \mathrm{Cl}: 0.14 \\
\text { to } 0.88 \\
\mathrm{I}^{2}=\mathrm{N} / \mathrm{A} \mathrm{I}^{2}\end{array}$ & $\begin{array}{l}1 \mathrm{RCT}^{15} \text { with } \\
214 \text { patients }\end{array}$ & $\begin{array}{l}\text { High ROB } \\
\text { and } \\
\text { imprecision }\end{array}$ & $\begin{array}{l}\text { Low SOE } \\
\text { supporting } \\
\text { improvement }\end{array}$ \\
\hline & $\begin{array}{l}\text { Need for Intubation } \\
\text { Longest Followup }\end{array}$ & $\begin{array}{l}\text { OR: } 0.13 ; \\
95 \% \mathrm{Cl}: 0.02 \\
\text { to } 1.00 \\
\mathrm{I}^{2}=\mathrm{N} / \mathrm{A}\end{array}$ & $\begin{array}{l}1 \mathrm{RCT}^{15} \text { with } \\
214 \text { patients }\end{array}$ & $\begin{array}{l}\text { High ROB } \\
\text { and severe } \\
\text { imprecision }\end{array}$ & $\begin{array}{l}\text { Insufficient } \\
\text { evidence }\end{array}$ \\
\hline \multirow[t]{2}{*}{$\begin{array}{l}\text { Titrated oxygen vs free } \\
\text { flow oxygen }\end{array}$} & $\begin{array}{l}\text { Mortality } \\
\text { End of Intervention }\end{array}$ & $\begin{array}{l}\text { OR: } 1.00 ; \\
95 \% \mathrm{Cl}: 0.06 \\
\text { to } 16.93 \\
\mathrm{I}^{2}=\mathrm{N} / \mathrm{A}\end{array}$ & $\begin{array}{l}1 \mathrm{RCT}^{30} \text { with } 50 \\
\text { patients }\end{array}$ & $\begin{array}{l}\text { Intermediate } \\
\text { ROB and } \\
\text { severe } \\
\text { imprecision }\end{array}$ & $\begin{array}{l}\text { Insufficient } \\
\text { evidence }\end{array}$ \\
\hline & $\begin{array}{l}\text { Need for intubation } \\
\text { End of intervention }\end{array}$ & $\begin{array}{l}\text { OR: } 3.12 ; \\
95 \% \text { Cl: } 0.12 \\
\text { to } 80.39 \\
I^{2}=N / A\end{array}$ & $\begin{array}{l}1 \mathrm{RCT}^{30} \text { with } 50 \\
\text { patients }\end{array}$ & $\begin{array}{l}\text { Intermediate } \\
\text { ROB and } \\
\text { severe } \\
\text { imprecision }\end{array}$ & $\begin{array}{l}\text { Insufficient } \\
\text { evidence }\end{array}$ \\
\hline
\end{tabular}




\begin{tabular}{|c|c|c|c|c|c|}
\hline & $\begin{array}{l}\text { Hospital } \\
\text { Readmissions } \\
30 \text { days }\end{array}$ & $\begin{array}{l}\text { OR: } 1.00 ; \\
95 \% \mathrm{Cl}: 0.27 \\
\text { to } 3.66 \\
\mathrm{I}^{2}=\mathrm{N} / \mathrm{A}\end{array}$ & $\begin{array}{l}1 \mathrm{RCT}^{30} \text { with } 50 \\
\text { patients }\end{array}$ & $\begin{array}{l}\text { Intermediate } \\
\text { ROB and } \\
\text { severe } \\
\text { imprecision }\end{array}$ & $\begin{array}{l}\text { Insufficient } \\
\text { evidence }\end{array}$ \\
\hline & $\begin{array}{l}\text { Hospital } \\
\text { Readmissions } \\
\text { Longest Followup }\end{array}$ & $\begin{array}{l}\text { OR: } 1.63 ; \\
95 \% \mathrm{Cl}: 0.53 \\
\text { to } 4.98 \\
\mathrm{I}^{2}=\mathrm{N} / \mathrm{A}\end{array}$ & $\begin{array}{l}1 \mathrm{RCT}^{30} \text { with } 50 \\
\text { patients }\end{array}$ & $\begin{array}{l}\text { Intermediate } \\
\text { ROB and } \\
\text { severe } \\
\text { imprecision }\end{array}$ & $\begin{array}{l}\text { Insufficient } \\
\text { evidence }\end{array}$ \\
\hline & $\begin{array}{l}\text { ICU Admission } \\
\text { End of Intervention }\end{array}$ & $\begin{array}{l}\text { OR: } 3.12 ; \\
95 \% \mathrm{Cl}: 0.12 \\
\text { to } 80.39 \\
\mathrm{l}^{2}=\mathrm{N} / \mathrm{A}\end{array}$ & $\begin{array}{l}1 \mathrm{RCT}^{30} \text { with } 50 \\
\text { patients }\end{array}$ & $\begin{array}{l}\text { Intermediate } \\
\text { ROB and } \\
\text { severe } \\
\text { imprecision }\end{array}$ & $\begin{array}{l}\text { Insufficient } \\
\text { evidence }\end{array}$ \\
\hline \multirow[t]{3}{*}{$\begin{array}{l}\text { Dietary intervention using } \\
\text { a caloric supplement } \\
\text { during AECOPD versus } \\
\text { usual diet }\end{array}$} & $\begin{array}{l}\text { Mortality } \\
\text { End of Intervention }\end{array}$ & $\begin{array}{l}\text { OR: } 0.81 ; \\
95 \% \mathrm{Cl}: 0.05 \\
\text { to } 14.28,1^{2}= \\
\text { N/A }\end{array}$ & $\begin{array}{l}1 \mathrm{RCT}^{37} \text { with } 31 \\
\text { patients }\end{array}$ & $\begin{array}{l}\text { High ROB } \\
\text { and severe } \\
\text { imprecision }\end{array}$ & $\begin{array}{l}\text { Insufficient } \\
\text { evidence }\end{array}$ \\
\hline & $\begin{array}{l}\text { Dyspnea } \\
\text { (Questionnaire: } \\
\text { Oxygen Cost } \\
\text { Diagram) } \\
\text { End of Intervention } \\
\end{array}$ & $\begin{array}{l}\text { WMD: 05.95; } \\
95 \% \mathrm{Cl}:- \\
5.74 \text { to } \\
17.64, \mathrm{I}^{2}= \\
\text { N/A }\end{array}$ & $\begin{array}{l}1 \mathrm{RCT}^{37} \text { with } 31 \\
\text { patients }\end{array}$ & $\begin{array}{l}\text { High ROB } \\
\text { and } \\
\text { imprecision }\end{array}$ & $\begin{array}{l}\text { Insufficient } \\
\text { evidence }\end{array}$ \\
\hline & $\begin{array}{l}\text { QoL(General Well- } \\
\text { Being) } \\
\text { End of Intervention }\end{array}$ & $\begin{array}{l}\text { WMD: } 22.21 \\
95 \% \mathrm{Cl}:- \\
6.99 \text { to } \\
151.40, \mathrm{I}^{2}= \\
\text { N/A }\end{array}$ & $\begin{array}{l}1 \mathrm{RCT}^{37} \text { with } 31 \\
\text { patients }\end{array}$ & $\begin{array}{l}\text { High ROB } \\
\text { and } \\
\text { imprecision }\end{array}$ & $\begin{array}{l}\text { Insufficient } \\
\text { evidence }\end{array}$ \\
\hline $\begin{array}{l}\text { Dietary intervention using } \\
\text { a caloric and a protein } \\
\text { supplement during } \\
\text { AECOPD versus } \\
\text { placebo(non-caloric fluid, } \\
\text { vanilla flavored water) }\end{array}$ & $\begin{array}{l}\text { Dyspnea } \\
\text { (Numeric Scale: } \\
\text { VAS, dyspnea } \\
\text { score while eating) } \\
\text { End of Intervention }\end{array}$ & $\begin{array}{l}\text { WMD: } 0.5 \\
95 \% \mathrm{Cl}:- \\
1.14 \text { to } 2.14 \\
\mathrm{I}^{2}=\mathrm{N} / \mathrm{A}\end{array}$ & $\begin{array}{l}1 \mathrm{RCT}^{43} \text { with } 47 \\
\text { patients }\end{array}$ & $\begin{array}{l}\text { High ROB } \\
\text { and severe } \\
\text { imprecision }\end{array}$ & $\begin{array}{l}\text { Insufficient } \\
\text { evidence }\end{array}$ \\
\hline \multirow[t]{3}{*}{$\begin{array}{l}\text { Dietary intervention using } \\
\text { omega-3 fatty acid } \\
\text { versus usual diet }\end{array}$} & $\begin{array}{l}\text { QoL (CAT) } \\
\text { End of Intervention }\end{array}$ & $\begin{array}{l}\text { WMD: } 0.00 \\
95 \% \mathrm{Cl}:- \\
3.46 \text { to } 3.46 \\
\left.\right|^{2}=\mathrm{N} / \mathrm{A}\end{array}$ & $\begin{array}{l}1 \mathrm{RCT}^{32} \text { with } 50 \\
\text { patients }\end{array}$ & $\begin{array}{l}\text { Severe } \\
\text { imprecision }\end{array}$ & $\begin{array}{l}\text { Low SOE } \\
\text { supporting no } \\
\text { difference }\end{array}$ \\
\hline & $\begin{array}{l}\text { Need for Intubation } \\
\text { End of Intervention }\end{array}$ & $\begin{array}{l}\text { OR: } 0.18 ; \\
95 \% \mathrm{Cl}: 0.01 \\
\text { to } 4.04, \mathrm{I}^{2}= \\
\text { N/A }\end{array}$ & $\begin{array}{l}1 \mathrm{RCT}^{32} \text { with } 50 \\
\text { patients }\end{array}$ & $\begin{array}{l}\text { Severe } \\
\text { imprecision }\end{array}$ & $\begin{array}{l}\text { Low SOE } \\
\text { supporting no } \\
\text { difference }\end{array}$ \\
\hline & $\begin{array}{l}\text { Dyspnea } \\
\text { (Questionnaire: } \\
\text { MMRC) } \\
\text { End of intervention }\end{array}$ & $\begin{array}{l}\text { WMD: } 0.00 \\
95 \% \mathrm{Cl}:- \\
0.55 \text { to } 0.55 \\
\mathrm{I}^{2}=\mathrm{N} / \mathrm{A}\end{array}$ & $\begin{array}{l}1 \mathrm{RCT}^{32} \text { with } 50 \\
\text { patients }\end{array}$ & $\begin{array}{l}\text { Severe } \\
\text { imprecision }\end{array}$ & $\begin{array}{l}\text { Low SOE } \\
\text { supporting no } \\
\text { difference }\end{array}$ \\
\hline \multirow[t]{5}{*}{$\begin{array}{l}\text { Dietary intervention using } \\
\text { vitamin } D \text { during } \\
\text { AECOPD versus placebo }\end{array}$} & $\begin{array}{l}\text { Mortality } \\
\text { Longest Followup }\end{array}$ & $\begin{array}{l}\text { OR: } 1.55 \\
95 \% \mathrm{Cl}: 0.24 \\
\text { to } 9.88, \mathrm{I}^{2}= \\
\text { N/A }\end{array}$ & $\begin{array}{l}1 \mathrm{RCT}^{35} \text { with } 70 \\
\text { patients }\end{array}$ & $\begin{array}{l}\text { High ROB } \\
\text { and severe } \\
\text { imprecision }\end{array}$ & $\begin{array}{l}\text { Insufficient } \\
\text { evidence }\end{array}$ \\
\hline & $\begin{array}{l}\text { Dyspnea } \\
\text { (Questionnaire: } \\
\text { MMRC) } \\
\text { End of Intervention }\end{array}$ & $\begin{array}{l}\text { SMD: }-0.11 \\
95 \% \mathrm{Cl}:-0.42 \\
\text { to } 0.20 \\
\mathrm{I}^{2}=0.00 \%\end{array}$ & $\begin{array}{l}2 \mathrm{RCTs}^{3536} \text { with } \\
160 \text { patients }\end{array}$ & $\begin{array}{l}\text { High ROB } \\
\text { and severe } \\
\text { imprecision }\end{array}$ & $\begin{array}{l}\text { Insufficient } \\
\text { evidence }\end{array}$ \\
\hline & $\begin{array}{l}\text { Dyspnea } \\
\text { (Questionnaire: } \\
\text { MMRC) } \\
\text { Longest Followup }\end{array}$ & $\begin{array}{l}\text { SMD: } 0.27 \\
95 \% \mathrm{Cl}:-0.09 \\
\text { to } 0.63, \mathrm{I}^{2}= \\
\text { N/A }\end{array}$ & $\begin{array}{l}1 \mathrm{RCT}^{35} \text { with } \\
70 \text { patients }\end{array}$ & $\begin{array}{l}\text { High ROB } \\
\text { and severe } \\
\text { imprecision }\end{array}$ & $\begin{array}{l}\text { Insufficient } \\
\text { evidence }\end{array}$ \\
\hline & $\begin{array}{l}\text { QoL(SGRQ) } \\
\text { End of Intervention }\end{array}$ & $\begin{array}{l}\text { WMD: }-1.96 ; \\
95 \% \mathrm{Cl}:-2.89 \\
\text { to }-1.03, \mathrm{I}^{2}= \\
\text { N/A }\end{array}$ & $\begin{array}{l}1 \mathrm{RCT}^{35} \text { with } 70 \\
\text { patients }\end{array}$ & $\begin{array}{l}\text { High ROB } \\
\text { and } \\
\text { imprecision }\end{array}$ & $\begin{array}{l}\text { Low SOE } \\
\text { supporting } \\
\text { improvement }\end{array}$ \\
\hline & $\begin{array}{l}\text { QoL(SGRQ) } \\
\text { Longest Followup }\end{array}$ & $\begin{array}{l}\text { WMD: }-4.67 ; \\
95 \% \mathrm{Cl}:- \\
6.00 \text { to }-3.35 \\
\mathrm{I}^{2}=\mathrm{N} / \mathrm{A}\end{array}$ & $\begin{array}{l}1 \mathrm{RCT}^{35} \text { with } 70 \\
\text { patients }\end{array}$ & $\begin{array}{l}\text { High ROB } \\
\text { and } \\
\text { imprecision }\end{array}$ & $\begin{array}{l}\text { Low SOE } \\
\text { supporting } \\
\text { improvement }\end{array}$ \\
\hline
\end{tabular}

$6 \mathrm{MWD}=$ six minute walking distance; $\mathrm{CAT}=\mathrm{COPD}$ assessment test $\mathrm{CI}=$ confidence interval; $\mathrm{CRQ}=$ chronic respiratory disease questionnaire; EQ-5D = EuroQol 5 dimensions; ICU = intensive care unit; MMRC = modified medical research 
council scale; $\mathrm{MRC}=$ medical research council scale; $\mathrm{N} / \mathrm{A}=$ not applicable; $\mathrm{OR}=$ odds ratio; $\mathrm{QoL}=$ quality of life; $\mathrm{RCT}=$ randomized controlled trial; ROB $=$ risk of bias; $\mathrm{SGRQ}=$ St. George respiratory questionnaire; $\mathrm{SMD}=$ standardized mean difference; $\mathrm{SOE}=$ strength of evidence; VAS = visual analog scale; WMD = weighted mean difference

Grey colored fields denote a statistically significant result favoring the intervention 


\section{References}

1. Patil SP, Krishnan JA, Lechtzin N, Diette GB. In-hospital mortality following acute exacerbations of chronic obstructive pulmonary disease. Arch Intern Med. 2003;163(10):1180-1186.

2. Seemungal TA, Donaldson GC, Paul EA, Bestall JC, Jeffries DJ, Wedzicha JA. Effect of exacerbation on quality of life in patients with chronic obstructive pulmonary disease. Am J Respir Crit Care Med. 1998;157(5 Pt 1):1418-1422.

3. Aaron SD. Management and prevention of exacerbations of COPD. Bmj. 2014;349:g5237.

4. Rodriguez-Roisin R. COPD exacerbations.5: management. Thorax. 2006;61(6):535-544.

5. Beasley R, Chien J, Douglas J, et al. Target oxygen saturation range: 92-96\% Versus 94-98. Respirology. 2017;22(1):200-202.

6. McCarthy B, Casey D, Devane D, Murphy K, Murphy E, Lacasse Y. Pulmonary rehabilitation for chronic obstructive pulmonary disease. Cochrane Database Syst Rev. 2015(2):Cd003793.

7. Law S, Kumar P, Woods S, Sriram KB. Malnutrition screening in patients admitted to hospital with an exacerbation of chronic obstructive pulmonary disease and its association with patient outcomes. Hospital practice (1995). 2016;44(4):207-212.

8. Spencer L. Pulmonary rehabilitation for patients with acute chronic obstructive pulmonary disease exacerbations: is the evidence strengthening? Current opinion in pulmonary medicine. 2018;24(2):147-151.

9. Schols AM, Ferreira IM, Franssen FM, et al. Nutritional assessment and therapy in COPD: a European Respiratory Society statement. Eur Respir J. 2014;44(6):1504-1520.

10. Higgins JPT, Green S, eds. Cochrane handbook for systematic reviews of interventions Version 5.1.0 [updated March 2011]. The Cochrane Collaboration; 2011.

11. DerSimonian R, Laird N. Meta-analysis in clinical trials. Control Clin Trials. 1986;7(3):177-188.

12. Guyatt $\mathrm{G}$, Rennie D, Meade M, Cook D, American Medical Association. Users' guides to the medical literature. A manual for evidence-based clinical practice. Third edition. ed. New York: McGraw-Hill Education Medical; 2015.

13. Ioannidis JP, Trikalinos TA. The appropriateness of asymmetry tests for publication bias in meta-analyses: a large survey. Canadian Medical Association Journal. 2007;176(8):10911096.

14. Berkman ND, Lohr KN, Ansari MT, et al. Grading the strength of a body of evidence when assessing health care interventions: an EPC update. Journal of clinical epidemiology. 2015;68(11):1312-1324.

15. Austin MA, Wills KE, Blizzard L, Walters EH, Wood-Baker R. Effect of high flow oxygen on mortality in chronic obstructive pulmonary disease patients in prehospital setting: randomised controlled trial. Bmj. 2010;341:c5462.

16. Basri R, Tahir M, Naseem M. Short-term effects of chest physiotherapy in acute exacerbation of chronic obstructive pulmonary disease. Journal of Medical Sciences (Peshawar). 2017;25(3):323-327.

17. Behnke M, Taube C, Kirsten D, Lehnigk B, Jorres RA, Magnussen H. Home-based exercise is capable of preserving hospital-based improvements in severe chronic obstructive pulmonary disease. Respir Med. 2000;94(12):1184-1191.

18. Borges RC, Carvalho CR. Impact of resistance training in chronic obstructive pulmonary disease patients during periods of acute exacerbation. Arch Phys Med Rehabil. 2014;95(9):1638-1645.

19. Brown PM, Manfreda J, McCarthy DS, MacDonald S. The effect of mechanical vibration in patients with acute exacerbations of chronic obstructive pulmonary disease. Physiother Can. 1987;39(6):371-374. 
20. Cox M, Connor C, Biggs $\mathrm{K}$, et al. The feasibility of early pulmonary rehabilitation and activity after COPD exacerbations: External pilot randomised controlled trial, qualitative case study and exploratory economic evaluation. Health Technol Assess. 2018;22(11).

21. Cross JL, Elender F, Barton G, et al. Evaluation of the effectiveness of manual chest physiotherapy techniques on quality of life at six months post exacerbation of COPD (MATREX): a randomised controlled equivalence trial. BMC polm. 2012;12:33.

22. Eaton $\mathrm{T}$, Young $\mathrm{P}$, Fergusson $\mathrm{W}$, et al. Does early pulmonary rehabilitation reduce acute health-care utilization in COPD patients admitted with an exacerbation? A randomized controlled study. Respirology. 2009;14(2):230-238.

23. Goktalay T, Akdemir SE, Alpaydin AO, Coskun AS, Celik P, Yorgancioglu A. Does highfrequency chest wall oscillation therapy have any impact on the infective exacerbations of chronic obstructive pulmonary disease? A randomized controlled single-blind study. Clin Rehabil. 2013;27(8):710-718.

24. Greening NJ, Williams JEA, Hussain SF, et al. An early rehabilitation intervention to enhance recovery during hospital admission for an exacerbation of chronic respiratory disease: randomised controlled trial. BMJ : British Medical Journal. 2014;349:g4315.

25. Greulich T, Nell C, Koepke J, et al. Benefits of whole body vibration training in patients hospitalised for COPD exacerbations - a randomized clinical trial. BMC polm. 2014;14:60.

26. He M, Yu S, Wang L, Lv H, Qiu Z. Efficiency and safety of pulmonary rehabilitation in acute exacerbation of chronic obstructive pulmonary disease. Med Sci Monit. 2015;21:806-812.

27. Kirsten DK, Taube C, Lehnigk B, Jorres RA, Magnussen H. Exercise training improves recovery in patients with COPD after an acute exacerbation. Respir Med. 1998;92(10):1191-1198.

28. Kodric M, Garuti G, Colomban M, et al. The effectiveness of a bronchial drainage technique (ELTGOL) in COPD exacerbations. Respirology. 2009;14(3):424-428.

29. Kurzaj M, Wierzejski W, Dor A, Stawska J, Rozek K. The impact of specialized physiotherapy methods on BODE index in COPD patients during hospitalization. Adv. 2013;22(5):721-730.

30. Lellouche $F$, Bouchard PA, Roberge $M$, et al. Automated oxygen titration and weaning with FreeO<inf $>2</$ inf $>$ in patients with acute exacerbation of COPD: A pilot randomized trial. International Journal of COPD. 2016;11(1):1983-1990.

31. Liao L-Y, Chen K-M, Chung W-S, Chien J-Y. Efficacy of a respiratory rehabilitation exercise training package in hospitalized elderly patients with acute exacerbation of COPD: a randomized control trial. International Journal of Copd. 2015;10:1703-1709.

32. Ogasawara T, Marui S, Miura E, et al. Effect of eicosapentaenoic acid on prevention of lean body mass depletion in patients with exacerbation of chronic obstructive pulmonary disease: A prospective randomized controlled trial. Clin Nutr ESPEN. 2018;28:67-73.

33. Oncu E, Zincir $\mathrm{H}$. The effect of transcutaneous electrical nerve stimulation in patients with acute exacerbation of chronic obstructive pulmonary disease: randomised controlled trial. $J$ Clin Nurs. 2017;26(13-14):1834-1844.

34. Osadnik CR, McDonald CF, Miller BR, et al. The effect of positive expiratory pressure (PEP) therapy on symptoms, quality of life and incidence of re-exacerbation in patients with acute exacerbations of chronic obstructive pulmonary disease: a multicentre, randomised controlled trial. Thorax. 2014;69(2):137-143.

35. Pourrashid MH, Dastan F, Salamzadeh J, Eslaminejad A, Edalatifard M. Role of vitamin D replacement on health related quality of life in hospitalized patients with "acute exacerbation of chronic obstructive pulmonary disease". Iranian Journal of Pharmaceutical Research. 2018;17(2):801-810.

36. Sanjari M, Soltani A, Habibi Khorasani A, Zareinejad M. The effect of vitamin D on COPD exacerbation: a double blind randomized placebo-controlled parallel clinical trial. J. 2015;15(1):33. 
37. Saudny-Unterberger H, Martin JG, Gray-Donald K. Impact of nutritional support on functional status during an acute exacerbation of chronic obstructive pulmonary disease. Am J Respir Crit Care Med. 1997;156(3 Pt 1):794-799.

38. Tang CY, Blackstock FC, Clarence M, Taylor NF. Early rehabilitation exercise program for inpatients during an acute exacerbation of chronic obstructive pulmonary disease: a randomized controlled trial. J Mol Signal. 2012;32(3):163-169.

39. Torres-Sánchez I, Valenza MC, Cebriá i Iranzo MDÀ, López-López L, Moreno-Ramírez MP, Ortíz-Rubio A. Effects of different physical therapy programs on perceived health status in acute exacerbation of chronic obstructive pulmonary disease patients: a randomized clinical trial. Disabil Rehabil. 2017:1-7.

40. Torres-Sanchez I, Valenza MC, Cabrera-Martos I, Lopez-Torres I, Benitez-Feliponi A, CondeValero A. Effects of an Exercise Intervention in Frail Older Patients with Chronic Obstructive Pulmonary Disease Hospitalized due to an Exacerbation: A Randomized Controlled Trial. Copd. 2017;14(1):37-42.

41. Troosters T, Probst VS, Crul T, et al. Resistance training prevents deterioration in quadriceps muscle function during acute exacerbations of chronic obstructive pulmonary disease. Am J Respir Crit Care Med. 2010;181(10):1072-1077.

42. Tumer G, Mercanligil SM, Uzun O, Aygun C. The effects of a high-fat, low-carbohydrate diet on the prognosis of patients with an acute attack of chronic obstructive pulmonary disease. Turkiye Klinikleri Journal of Medical Sciences. 2009;29(4):895-904.

43. Vermeeren MAP, Wouters EFM, Geraerts-Keeris AJW, Schols AMWJ. Nutritional support in patients with chronic obstructive pulmonary disease during hospitalization for an acute exacerbation; a randomized controlled feasibility trial. Clin Nutr. 2004;23(5):1184-1192.

44. Yohannes AM, Connolly MJ. Early mobilization with walking aids following hospital admission with acute exacerbation of chronic obstructive pulmonary disease. Clin Rehabil. 2003;17(5):465-471.

45. Osadnik CR, McDonald CF, Jones AP, Holland AE. Airway clearance techniques for chronic obstructive pulmonary disease. Cochrane Database Syst Rev. 2012(3):Cd008328.

46. Bellone A, Spagnolatti L, Massobrio M, et al. Short-term effects of expiration under positive pressure in patients with acute exacerbation of chronic obstructive pulmonary disease and mild acidosis requiring non-invasive positive pressure ventilation. Intensive Care Med. 2002;28(5):581-585.

47. Inal-Ince D, Savci S, Topeli A, Arikan H. Active cycle of breathing techniques in non-invasive ventilation for acute hypercapnic respiratory failure. Aust J Physiother. 2004;50(2):67-73.

48. Vargas F, Bui HN, Boyer A, et al. Intrapulmonary percussive ventilation in acute exacerbations of COPD patients with mild respiratory acidosis: a randomized controlled trial [ISRCTN17802078]. Crit Care. 2005;9(4):R382-389.

49. Newton DA, Bevans HG. Physiotherapy and intermittent positive-pressure ventilation of chronic bronchitis. Br Med J. 1978;2(6151):1525-1528.

50. Cross JL, Elender F, Barton $\mathrm{G}$, et al. Evaluation of the effectiveness of manual chest physiotherapy techniques on quality of life at six months post exacerbation of COPD (MATREX): a randomised controlled equivalence trial. BMC Pulm Med. 2012;12:33.

51. Kurzaj M, Wierzejski W, Dor A, Stawska J, Rozek K. The impact of specialized physiotherapy methods on BODE index in COPD patients during hospitalization. Advances in clinical and experimental medicine : official organ Wroclaw Medical University. 2013;22(5):721-730.

52. Goktalay T, Akdemir SE, Alpaydin AO, Coskun AS, Celik P, Yorgancioglu A. Does highfrequency chest wall oscillation therapy have any impact on the infective exacerbations of chronic obstructive pulmonary disease? A randomized controlled single-blind study. Clin Rehabil. 2013;27(8):710-718.

53. Wedzicha JA, Miravitlles M, Hurst JR, et al. Management of COPD exacerbations: A European respiratory society/American thoracic society guideline. Eur Respir J. 2017;49(3):1600791. 
54. Greening NJ, Williams JEA, Hussain SF, et al. An early rehabilitation intervention to enhance recovery during hospital admission for an exacerbation of chronic respiratory disease: randomised controlled trial. Bmj. 2014;349:g4315.

55. Behnke M, Taube C, Kirsten D, Lehnigk B, Jorres RA, Magnussen H. Home-based exercise is capable of preserving hospital-based improvements in severe chronic obstructive pulmonary disease. Respir Med. 2000;94(12):1184-1191.

56. (NICE) NIfHaCE. Chronic obstructive pulmonary disease in adults. 2011.

57. Corley A, Rickard CM, Aitken LM, et al. High-flow nasal cannulae for respiratory support in adult intensive care patients. Cochrane Database Syst Rev. 2017;5:Cd010172.

58. Lin SM, Liu KX, Lin ZH, Lin PH. Does high-flow nasal cannula oxygen improve outcome in acute hypoxemic respiratory failure? A systematic review and meta-analysis. Respir Med. 2017;131:58-64. 